\title{
OBITUARY
}

\section{Hardie de Beer, 8 August 1943 - 9 December 2017}

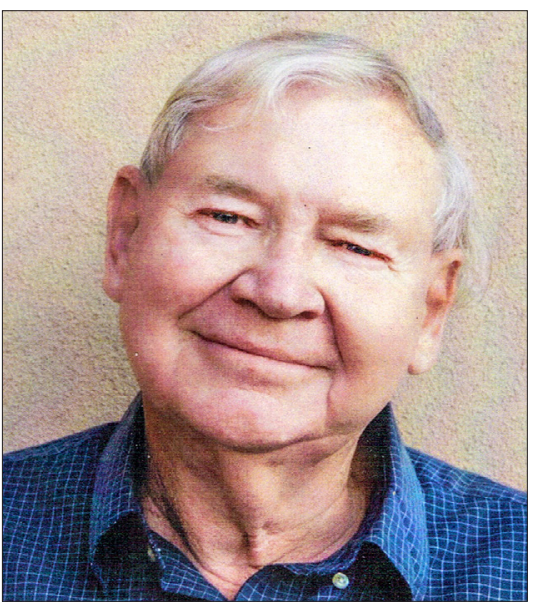

Dr Hardie de Beer was a beloved dermatologist who practised in Pretoria, South Africa, for many years. As a specialist, Hardie was always eager to explore and embrace new technologies. From the early days of laser, he had a $\mathrm{CO}_{2}$ laser instrument that he used daily in his consulting rooms. He was one of the first dermatologists to offer pulsed-dye laser to treat port-wine stains, and a pioneer with regard to full-face $\mathrm{CO}_{2}$ resurfacing. He also offered his patients sclerotherapy, as well as many other new technologies.

Hardie was an astute businessman and in addition to his medical practice he found the time to use his business skills. He was one of the founding shareholders of Life Wilgers Hospital in Pretoria. During the first, often difficult, years of starting the new hospi- tal, when some of the shareholders became concerned with its viability, he would offer to buy their shares. When the consortium sold the hospital to Life Healthcare, he owned a significant stake in the hospital, which is unusual for an individual doctor and certainly for a dermatologist. The combination of business acumen and willingness to venture into new dermatological territories, led him to develop a skincare range, Crème Classique. Starting from the house practice with boxes everywhere, he built up the business to a large concern that distributes its products through a national chain of pharmacies. This business continues, with his son as the CEO.

Hardie was always proud that, throughout his career, he was involved in property development. In the past few years he built houses in the Silver Lakes Golf Estate, Pretoria. Years ago, he and his partners developed a block of holiday flats on the KwaZulu-Natal south coast. He sold all the flats - many to patients who enquired about them after seeing an advertisement in his waiting room.

Hardie was also a successful farmer. With the same vigour and energy with which he pursued his practice and other business interests, he would approach his weekend farming near Kranskop, with his beloved cattle. Hardie would barely set foot on the farm, when he would start running around and giving orders, managing to do a week's farming on a Saturday. Not content with cattle only, he also pursued fish farming at some point.

Hardie even established a laser clinic in Manchester in the UK and travelled there to consult patients.

His undergraduate medical studies were completed at the University of Pretoria, where he obtained the $\mathrm{MB} \mathrm{ChB}$ degree in 1966. He then entered private practice as a general practitioner in Johannesburg, where he had a varied and busy practice, gaining experience in all aspects of general practice, including surgery. He specialised in dermatology under Prof. G Findlay at the University of Pretoria. After qualifying, he entered private practice, first in Pretoria at the Van Riebeeck Centre, eventually moving to a house in Pretorius Street. Hardie was a lifelong student, and during his career obtained the following qualifications, in addition to his basic medical and specialist degrees: MFGP (SA), MPracMed, DBG, DTM, MPharmMed, DGG, DGA, ECFMG.

During a visit to his daughter in the USA, he developed acute heart failure, which led to hospitalisation. During the following months his heart condition deteriorated, and in December 2017 Hardie passed away. He will be missed by many people whose lives he touched during his long career.

\section{Pieter du Plessis}

Dermatologist, Private practice, Pretoria, South Africa

info@skinmatters.co.za 